\title{
К ВОПРОСУ О СУПРУЖЕСКОЙ СОВМЕСТИМОСТИ
}

\author{
Я. В. Волобуев \\ Московский гуманитарный университет,
}

Аннотация: В статье проводится краткий обзор некоторых психологических теорий и подходов к исследовательской проблеме супружеской совместимости.

Ключевые слова: супружеская совместимость; брак; семья; психология семьи

\section{ON THE MATTER OF MARITAL COMPATIBILITY}

\author{
Ya. V. Volobuev \\ Moscow University for the Humanities
}

Abstract: The article provides a brief overview of some psychological theories and approaches to the research problem of marital compatibility.

Keywords: marital compatibility, marriage; family; family psychology

Проблема психологической совместимости партнеров - мужчины и женщины, и как следствие, их удовлетворенность отношениями - является одной из острых и актуальных для решения психологической наукой. В настоящее время внимание не только психологов, но и демографов, социологов все больше обращено к исследованию причин, влияющих на благополучие брака. Результаты исследований имеют как теоретическую ценность, так и практическую, поскольку дают инструментарий для практикующих специалистов по работе с супружескими парами.

Совместимость, с одной стороны - это похожесть друг на друга, близость во взглядах, а с другой - такое различие, когда характеры и привычки супругов не враждебны, а дополняют друг друга. Такие «совместные знаменатели» крайне важны для семейной жизни. Влюбляться можно в совершенно разных людей, но уживаться вместе и сохранять любовь на долгие годы можно только с совместимым человеком. Очень от многих факторов - эмоциональных, сексуальных, моральных, духовных зависит судьба брака: чем больше совместимых сторон в этих факторах, чем больше у партнеров близких сторон, тем лучше им друг с другом и тем дольше просуществует их союз. 
Цель данной статьи - сделать обзор научных исследований проблематики супружеской совместимости, посмотреть какие подходы существуют, прежде всего, в психологии, в том числе в зарубежной.

Например, А. Аугустинавичюте считает наиболее гармоничными те пары, где супруги имеют противоположные типы характеров: например, сочетание открытого, коммуникабельного человека и малообщительного, возможно, даже замкнутого (Аугустинавичюте, 2007). В противовес этому, Д. Майерс считает это суждение спорным, он склоняется к точке зрения, что люди как правило вступают в брак с теми, чьи потребности и личностные особенности похожи на их собственные (Майерс, 1997).

А. Кемпински же именно в схожести мужчины и женщины по многим личностным характеристикам видит основную причину непривлекательности партнеров друг для друга, что, в итоге, ведет к конфликтам и ссорам (Кемпински, 2002).

Ю. Орлов, С. Гильд и С. Хрусталев выделяют два подхода к пониманию супружеской совместимости: 1) совместимость как наборы качеств, которые сочетаются друг с другом (например, стремление лидировать у одного подкрепляется желанием подчиняться у другого); 2) совместимость, в центре которой у супругов лежит понимание друг друга, возможность уступать, поиск компромиссов при возможных конфликтах. Авторы считают, что первый подход прогнозирует, а второй - гарантирует успешность брака (Орлов, Гильд, Хрусталев, 2011).

Важно отметить, что совместимость партнеров неразрывна связана с их удовлетворенностью отношениями.

С. М. Сопун и А. Г. Лидерс из своего исследования делают вывод, что удовлетворенность браком напрямую зависит от совместимости супругов. Причем как межличностной совместимости, так и ценностной, смысловой - на уровне установок и взглядов (Сопун, Лидерс, 2007).

Совместимость и качество брачных отношений, по мнению многих психологов и исследователей, зависит от любви. Один из психологических словарей, определяет любовь так: «Любовь - это высшее духовное чувство человека, богатое разнообразными эмоциональными переживаниями, основанное на благородных чувствах и высокой морали и сопровождаемое готовностью сделать все от себя зависящее для благополучия любимого человека» (Психологический словарь, 1990: 203).

Р. Стернберг в своей концепции показывает, что любовь состоит из трех компонентов: 1) близости, интимности, искреннего обмена мыслями и чувствами, общих интересов; 2) страсти; 3) обязательств, ответственности (Стернберг, 2001).

Любовь является сильным чувством, позволяющим человеку давать другому необходимое, и, в тоже время, удовлетворять свои потребности. 
Различные исследования показывают, что не только в прошлом, но и сегодня, любовь играет важнейшую роль в формировании брачных отношений, без нее исчезает счастье семейной жизни и чувство удовлетворенности браком.

Также, совместимость тесно связана с коммуникацией между собой партнеров. Если можно сказать о совместимости двух людей, то можно и с высокой долей достоверности предположить, что качество коммуникации между ними высокая. Эффективность же коммуникации зависит от коммуникативных способностей человека (правильного использования средств коммуникации, культуры речи, эмпатии, общительности), а также от способности осознавать и преодолевать коммуникативные барьеры.

Особое внимание авторы (А. Г. Лидерс, М. Р. Битянова, Ю. В. Суховершинина, Е. П. Тихомирова, Ю. Е. Скоромная, Э. Г. Эйдемиллер, В. Юстицкис) отдают такой способности человека как эмпатия.

Межличностное общение супругов получается тем успешнее, чем больше взаимной эмпатии они проявляют в нем (без сопереживания, сочувствия, соучастия успешное межличностное общение между супругами невозможно) (Лидерс, 2006).

М. Р. Битянова отмечает, что эмпатия - это постижение эмоционального состояния, «вчувствование» в другого человека (Битянова, 2000).

Реализация эмпатии возможна в случае принятия партнера по общению в качестве безусловной ценности, которое связано с доверием, готовностью самому раскрыться на встречу другому, стать для него объектом переживания (Суховершина и др., 2009).

Э. Г. Эйдемиллер, В. Юстицкис в исследовании эмпатии у членов семьи, обратившихся за психотерапевтической помощь, установили низкий уровень эмпатии, особенно среди мужей и подростков, что дало исследователям основание думать о наличии коммуникационного барьера в общении (Эйдемиллер, Юстицкис, 2008).

То есть, мы можем выделить качества, которые в принципе хороши (универсальны) в плане совместимости с другими людьми (например, высокий уровень эмпатии). А есть качества (характер, различные личностные характеристики и особенности), которые подходят только под определенные типы партнеров.

Кроме личностных характеристик, важно, чтобы были общие взгляды на жизнь, на организацию досуга и быта. Общие цели и интересы. Похожие ценностные ориентиры. Все это, тоже, одна из весомых составляющих совместимости.

Так, например, Э. Г. Эйдемиллер, В. В. Юстицкис выявили, что резкое расхождения между реальной жизнью семьи и ожиданиями (особенно чрезмерно завышенным уровнем притязаний у молодых супругов) вызы- 
вает состояние фрустрации, и, как следствие, неудовлетворенности (Эйдемиллер, Юстицкис, 2008).

Не стоит забывать и про сексуальную совместимость, которая играет далеко не последнюю роль в отношениях мужчин и женщин.

Обзор показывает, что к вопросу супружеской совместимости можно подходить с разных сторон, рассматривать с разных позиций, и что поле для исследований в данной области очень широко. Совместимость партнеров - сложная и многоаспектная проблема.

\section{СПИСОК ЛИТЕРАТУРЫ}

Аугустинавичюте, А. (2007) Социон. М.: Чёрная белка. 192 с.

Битянова, М. Р. (2000) Познание и понимание людьми друг друга в процессе общения // Школьный психолог. № 27. С. 12-16.

Майерс, Д. (1997) Социальная психология: пер. с англ. СПб.: Питер. 688 с.

Орлов, Ю., Гильд, С., Хрусталев, С. (2011) Семья глазами психолога. М. : Владос. 263 с.

Лидерс, А. Г. (2006) Психологическое обследование семьи: учеб. пособие-практикум для студ. фак. психологии высш. учеб. заведений. 2-е изд., стер. М. : Академия. 432 с.

Кемпински, А. (2002) Меланхолия. М. : Наука. 405 с.

Психологический словарь (1990) / под общ. ред. А. В. Петровского, М. Г. Ярошевского. 2-е изд. М. : Политиздат. 494 с.

Сопун, С. М., Лидерс, А. Г. (2007) Психологическая совместимость супружеской пары и удовлетворенность браком // Сибирский психологический журнал. № 25. С. 156-162.

Суховершина, Ю. В., Тихомирова, Е. П., Скоромная, Ю. Е. (2009) Тренинг коммуникативной компетенции. 2-е изд. М. : Академический проект ; Фонд «Мир». 111 с.

Эйдемиллер, Э. Г., Юстицкис, В. (2008) Психология и психотерапия семьи. 4-е изд. СПб.: Питер. 672 с.

Дата поступления: 09.04.2017 г.

Волобуев Ярослав Валерьевич - магистрант кафедры общей психологии и истории психологии Московского гуманитарного университета. Адрес: 111395, Россия, г. Москва, ул. Юности, д. 5. Тел.: +7 (499) 374-67-20. Эл. адрес: voyar9@gmail.com. Научный руководитель - канд. псих. наук, проф. Т. С. Леви. 
Volobuev Yaroslav Valerievich, Graduate Student, Department of General Psychology and the History of Psychology, Moscow University for the Humanities. Postal address: 5, Yunosti St., Moscow, Russian Federation 111395. Tel.: +7 (499) 374-67-20.E-mail:voyar9@gmail.com. Scientific Adviser - T. S. Levi, Candidate of Psychology, Professor.

\section{Для цитирования:}

Волобуев Я. В. К вопросу о супружеской совместимости [Электронный ресурс] // Научные труды Московского гуманитарного университета. 2017, № 3. URL: http:// journals.mosgu.ru/trudy/article/view/500 (дата обращения: дд.мм.гг.). DOI: 10.17805/ trudy.2017.3.6 